TARNOWSKIE STUDIA TEOLOGICZNE 37 (2018) NR 1-2, S. 141-165

http://dx.doi.org/10.15633/tst.3256

ks. Stanisław Ludwik Piech ${ }^{1}$

UNIWERSYTET PAPIESKI JANA PAWŁA II W KRAKOWIE

\title{
Konstanty Michalski CM - historyk filozofii wieków średnich
}

Jednym z twórców kultury katolickiej pierwszej połowy xx stulecia był ks. Konstanty Michalski CM (1879-1947), filozof, profesor Uniwersytetu Jagiellońskiego. Był „pierwszym uczonym polskim, który pracując nad wyjaśnieniem głównych prądów w filozofii późniejszego średniowiecza na terenie Francji i Anglii w wieku xIv, wniósł w tej dziedzinie trwały i istotny dorobek w naukę europejską" ${ }^{2}$. Do tego dorobku naukowego - mimo upływu przeszło siedemdziesięciu lat od jego śmierci - wciąż odwołują się współcześni mediewiści. Warto zatem przypomnieć jego dokonania na gruncie badań nad filozofią wieków średnich ${ }^{3}$.

\section{Studia}

Konstanty Józef Michalski urodził się 12 kwietnia 1879 roku w Dąbrówce Małej (dziś w obrębie Katowic), w rodzinie hutnika Ignacego i Pauliny z Winklerów. Szkołę powszechną ukończył w Siemianowicach Śląskich. W 1896 roku wstąpił do Zgromadzenia Księży Misjonarzy św. Wincentego a Paulo. Szkołę średnią

\footnotetext{
1 Stanisław Ludwik Piech, ks. prof. dr hab. nauk humanistycznych, emerytowany profesor zwyczajny Uniwersytetu Papieskiego Jana Pawła II w Krakowie, wykładowca w Wyższej Szkole Kultury Społecznej i Medialnej w Toruniu; specjalności: historia kultury, dzieje Kościoła, historia Polski xvıII-xx wiek, historia Kościoła w Polsce.

2 R. Ingarden, Uczony - filozof - człowiek, w: K. Michalski, Dilatato corde, Kraków 2002, S. 567 .

3 W artykule korzystałem z moich wcześniejszych opracowań: Księdza Konstantego Michalskiego życie i dzieło. W pięćdziesiątą rocznicę śmierci, „Folia Historia Cracoviensia” 4-5 (1997-1998), s. 261-277, Wkład ks. Konstantego Michalskiego do skarbca kultury europejskiej, „Fides, Ratio et Patria. Studia Toruńskie” 6 (2017), s. 27-46, starając się bardziej uwydatnić i znacznie szerzej przedstawić jego osiągnięcia na polu badań nad filozofią średniowieczną.
} 
ukończył jako małoseminarzysta Prywatnego Gimnazjum Księży Misjonarzy w Krakowie. W 1900 roku złożył egzamin dojrzałości w Gimnazjum św. Anny (dziś I Liceum Ogólnokształcące im. B. Nowodworskiego). Studia filozoficzno-teologiczne odbył w Instytucie Teologicznym Księży Misjonarzy w Krakowie na Stradomiu i równocześnie słuchał wykładów na Wydziałach: Teologicznym i Filozoficznym Uniwersytetu Jagiellońskiego. Święcenia kapłańskie przyjął w 1903 roku w katedrze wawelskiej. Po święceniach, obok funkcji duszpasterskich spełniał obowiązki nauczycielskie w zakładach swego zgromadzenia. Uczył języka polskiego i literatury powszechnej w gimnazjum misjonarskim, klerykom zaś w Instytucie Teologicznym wykładał historię filozofii (od 1904) i patrologię (od 1906). Sam równocześnie w latach 1900-1906, z przerwą jednego roku studiował slawistykę na Wydziale Filozoficznym Uniwersytetu Jagiellońskiego. W misjonarskim Instytucie Teologicznym pełnił funkcję prefekta studiów i bibliotekarza. W latach 1906-1908 był katechetą w krakowskim gimnazjum żeńskim im. Heleny Kaplińskiej. W latach 1908-1911 studiował w Wyższym Instytucie Filozoficznym Uniwersytetu Katolickiego w Louvain, gdzie jego profesorami byli pierwsi i najbliżsi współpracownicy Désiré Josepha Merciera: Maurice De Wulf, Désiré Nys, Leon Noël i Albert Edouard Michotte van der Berck. Tam w 1910 roku uzyskał licencjat na podstawie pracy Mach et Duhem. Étude épistémologique comparée, zaś 15 lutego 1911 roku uzyskał stopień doktora filozofii na podstawie rozprawy: La réaction contre le psychologisme en Allemagne. Husserl, ses prédecésseurs et ses partisans. Po powrocie do Krakowa wykładał filozofię w Instytucie Teologicznym swego zgromadzenia (1911-1922).

\section{Profesor Uniwersytetu Jagiellońskiego}

Po nagłej śmierci Franciszka Gabryla był w latach 1914-1919 zastępcą profesora filozofii chrześcijańskiej i apologetyki na Wydziale Teologicznym Uniwersytetu Jagiellońskiego ${ }^{4}$. Habilitował się 26 listopada 1918 roku w tym uniwersytecie w zakresie filozofii chrześcijańskiej na podstawie dwóch rozpraw: Jan Buridanus i jego wplyw na filozofię scholastyczna w Polsce (niewydana drukiem) oraz Michał $z$ Biestrzykowa i Jan ze Stobnicy jako przedstawiciele skotyzmu

4 Archiwum Uniwersytetu Jagiellońskiego [dalej: AUJ], sygn. S II 619, Życiorys; S. Piech, Michalski Konstanty Józef, w: Encyklopedia filozofii polskiej, t. 2, Lublin 2011, s. 134-135. 
w Polsce $e^{5}$ Naczelnik państwa Józef Piłsudski postanowieniem z 14 maja 1919 roku zatwierdził jego habilitację i równocześnie mianował go profesorem filozofii chrześcijańskiej w Uniwersytecie Jagiellońskim ${ }^{6}$. W dwa lata później 24 sierpnia 1921 roku otrzymał nominację na profesora zwyczajnego ${ }^{7}$.

Michalski uczył filozofii na kursach I i II. Wykładał w duchu tomizmu lowańskiego. W wykładach i ćwiczeniach seminaryjnych, a także w swoich pismach najchętniej sięgał do myśli św. Tomasza z Akwinu, zwłaszcza do jego Sumy teologicznej, którą nazywał genialną syntezą. Święty Tomasz był dla niego „wielkim budowniczym myśli chrześcijańskiej, który otwarł ramiona i duszę na przyjęcie filozofii perypatetycznej, jako najpiękniejszego kwiatu Hellady. Nigdy przedtem ani nigdy potem nie było - zdaniem Michalskiego - bardziej znamiennego spotkania Logosu z Ewangelii z Logosem, który wypowiedział się w naturalnym myśleniu”" . Pragnienie wciągnięcia słuchaczy w krąg myśli i swego zachwytu prawdą sprawiało, że odsłaniał przed nimi całą głębię i rozległość swojej wiedzy w celu pobudzenia ich do wysiłku myślenia9. „W wykładach swych dbał nie tyle o przystępność, ile raczej o pogłębienie przedmiotu” - wspominał ks. Aleksander Usowicz cM, jego uczeń. „Dlatego trzeba było pewnego wysiłku ze strony słuchaczy, by zasymilować podawaną treść. Tego rodzaju metoda miała tę dobrą stronę, że pobudzała wszystkich do osobistego trudu, a zdolniejszych skłaniała do twórczej pracy. Rzeczywistą lub pozorną surowość przy egzaminach i kolokwiach wykładowca umiał okrasić swoistym humorem. Pełne zapału słowa zachęty znalazły się zawsze dla tych, co mieli chęć do rzetelnej pracy"10.

Oddziaływanie na młodzież ułatwiał mu dar żywego słowa. Studia slawistyki rozwinęły w nim talent wyrażania swych myśli w pięknych słowach i barwnych porównaniach. Umiał przemawiać bezpośrednio i oryginalnie, a zarazem

${ }^{5}$ Archiwum Komisji do Badania Historii Filozofii w Polsce, t. 1, cz. 1, Kraków 1915. Osob. odb. Kraków 1914.

${ }^{6}$ AUj, sygn. S II 619, Ministerstwo Wyznań Religijnych i Oświecenia Publicznego [dalej: Min. WRiop] do Wydz. Teolog. UJ, Warszawa 27.06.1919.

AUJ, sygn. S II 619, Min. Wriop do Rektoratu UJ, Warszawa 7.09.1921.

${ }^{8}$ K. Michalski, Filozofia wieków średnich, Kraków 1997, s. 294.

9 Szerzej o tematyce wykładów i ćwiczeń seminaryjnych pisałem w moich opracowaniach: Dzieje Wydziału Teologicznego Uniwersytetu Jagiellońskiego w latach 1880-1939, Kraków 1995, s. 120-121; Księdza Konstantego Michalskiego życie i dzieło. W pięćdziesiąta rocznicę śmierci, s. 263-264; Konstanty Józef Michalski (1879-1947), w: Złota Księga Papieskiej Akademii Teologicznej, red. S. Piech, Kraków 200o, s. 435-436.

10 A. Usowicz, Zbieracze złotych kłosów, Kraków 2012, s. 484. 
konkretnie i plastycznie. Kiedy był jakąś sprawą szczególnie przejęty, uczucie niby wewnętrzny ogień rozświetlało jego słowa wydobywane z głębi myśli. $\mathrm{W}$ relacjach ze studentami nie było w nim „nic z typowego pedagoga, urabiającego silną ręką uczniów na podobieństwo swoich osobistych przekonań - był zawsze tylko przyjacielem, który się głębią myśli z każdym jak równy z równym dzielił, powodowany nie tyle chęcią nauczania, co pragnieniem dopuszczenia drugich do tej radości, jaką dawało mu coraz istotniejsze poznawanie prawdy" ${ }^{\prime 1}$.

Michalski w okresie swojej profesury na Wydziale Teologicznym UJ, jako ekspert Komisji Specjalnej Delegacji Polskiej w Moskwie, pracował w Petersburskiej Bibliotece Publicznej nad rewindykacją zagrabionych w Polsce rękopisów średniowiecznych z zakresu teologii, prawa kanonicznego i polskiego. W czasie dwukrotnego pobytu w Petersburgu w 1923 roku sporządził w tamtejszej bibliotece katalog 4500 rękopisów z oznaczeniem ich polskiej proweniencji ${ }^{12}$.

\section{Działalność naukowo-organizacyjna}

Czterokrotnie był dziekanem Wydziału Teologicznego (1923/24, 1928/29, 1935/36, 1936/37). W roku akademickim 1931/32 piastował godność rektora Uniwersytetu Jagiellońskiego. Na tym stanowisku zajął się rozbudową Biblioteki Jagiellońskiej, odpowiednim doborem sił nauczycielskich, wyposażeniem zakładów i zacieśnieniem kontaktów naukowych z zagranicą. Mocno związany z Uniwersytetem Jagiellońskim nie przyjął zaszczytnych propozycji przeniesienia się w 1931 roku na Uniwersytet Warszawski, w 1939 roku do Wolnej Wszechnicy Polskiej i w 1944 roku na Katolicki Uniwersytet Lubelski ${ }^{13}$.

Michalski od 1914 roku był współpracownikiem, a od 1918 roku sekretarzem Komisji do Badań Historii Filozofii w Polsce w Akademii Umiejętności (PAU) ${ }^{14}$. 10 czerwca 1927 roku został członkiem korespondentem Wydziału HistorycznoFilozoficznego PAU. Od 16 czerwca 1933 roku był już członkiem czynnym tej najpoważniejszej polskiej instytucji naukowej. W latach 1937/38-1939/40 był członkiem Wyższej Komisji Dyscyplinarnej dla profesorów państwowych szkół

${ }^{11}$ M. Morstin-Górska, Przyjaciel serc ludzkich, w: 70 żywotów, wybór i red. A. Pa1uchowski, Kraków 1977, s. 221.

12 AUJ, sygn. S II 987, Wielka kronika UJ, Rękopisy i notaty 1914-1925.

${ }_{13}$ M. Markowski, Konstanty Michalski (I879-1947), „Studia Mediewistyczne” 26 (1989) z. 1, s. 8 .

${ }^{14}$ A. Usowicz, K. Kłósak, Ksiądz Konstanty Michalski (I879-1947), Kraków 1949, s. 64. 
akademickich przy ministrze wyznań religijnych i oświecenia publicznego ${ }^{15}$. W latach 1938-1947 pełnił w PAU obowiązki przewodniczącego Komisji Historii Filozofii w Polsce i wicedyrektora Wydziału Historyczno-Filozoficznego (19451947). Był przewodniczącym Komitetu Wydawnictw Śląskich (1933-1939). W latach 1928-1947 sprawował funkcję delegata Polskiej Akademii Umiejętności do Międzynarodowej Unii Akademii (Union Académique Internationale) w Brukseli ${ }^{16}$. Z jego inicjatywy utworzono w Krakowie w 1924 roku Naukowy Instytut Katolicki, którego celem było krzewienie kultury chrześcijańskiej wśród inteligencji poprzez doborową bibliotekę, odczyty oraz skupienie przy sobie stowarzyszeń katolickich ${ }^{17}$.

\section{Schyłek życia}

6 listopada 1939 roku aresztowany razem $\mathrm{z}$ innymi profesorami Uniwersytetu w Collegium Novum, w osławionej „Sonderaktion Krakau”, został przewieziony do więzienia we Wrocławiu, a następnie do obozu koncentracyjnego w Sachsenhausen koło Berlina. Tam spotkał się z gehenną jakby wyjętą z kręgów dantejskiego piekła. W obozie nie szczędzono mu dodatkowych cierpień tylko dlatego, że był kapłanem. Zwolniony z obozu z początkiem lutego 1940 roku, przebywał trzy tygodnie $\mathrm{w}$ Krakowie. Na zaproszenie biskupa sandomierskiego Jana Kantego Lorka см i księstwa Zofii z Popielów i Krzysztofa Radziwiłłów udał się do Sichowa koło Staszowa. Tam w chwilach wolnych od zajęć duszpasterskich pisał pracę Między heroizmem a bestialstwem, w dużej mierze inspirowaną przeżyciami obozowymi. W marcu 1945 roku podjął na nowo swoje obowiązki na Wydziale Teologicznym uj. Latem 1946 roku głosił w Częstochowie rekolekcje dla episkopatu polskiego. Za swoje zasługi w dziedzinie nauki otrzymał Krzyż Komandorski Orderu Polonia Restituta (1936) oraz francuski Krzyż Oficerski Legii Honorowej (1937). W 1940 roku został członkiem Pontificia Accademia di S. Tommaso d’Aquino e di Religione Cattolica. Żył już niedługo. Zmarł w Krakowie 6 sierpnia 1947 roku i został

15 Archiwum Akt Nowych w Warszawie, sygn. Mwriop 4359, Min. wriop do ks. K. Michalskiego, [b.d.] XI 1937.

${ }^{16}$ E. Nieciowa, Członkowie Akademii Umiejętności oraz Polskiej Akademii Umiejętności 1872-1952, Wrocław-Kraków 1973, s. 17, 94.

${ }^{17}$ S. Piech, W cieniu kościołów i synagog. Życie religijne międzywojennego Krakowa 1918 1939, Kraków 1999, s. 70-72. 
pochowany w grobowcu Zgromadzenia Księży Misjonarzy na Cmentarzu Rakowickim w Krakowie.

\section{Geneza zainteresowań historią filozofii średniowiecznej}

Michalski najwięcej czasu i trudu poświęcił myśli średniowiecznej. Filozofia ta, niedoceniana w czasach odrodzenia, zapomniana przez uczonych nowożytnych i lekceważona przez pozytywistów, zamknięta w starych kodeksach rękopiśmiennych czekała na swój renesans. Dopiero w drugiej połowie XIX stulecia na nowo zainteresowano się życiem umysłowym wieków średnich. Doniosłą rolę w ożywieniu badań historycznofilozoficznych odegrała ogłoszona w 1879 roku przez Leona xıı encyklika Aeterni Patris. Papież wzywał w niej uczonych katolickich do badań nad filozofią scholastyczną, zwłaszcza nad myślą św. Tomasza z Akwinu. Leon xiıI nie tylko nawoływał do studiowania filozofii średniowiecznej, ale także wskazywał, że myśl scholastyczna (a zwłaszcza tomizm) wcale nie pozostaje w sprzeczności z nowożytną fizyką i filozofią społeczną ani nie jest jej wroga. Przeciwnie, dobrze zrozumiany i filozoficznie pogłębiony tomizm może się stać platformą zespolenia w jedną całość wielu zdezintegrowanych nauk o świecie i człowieku. Na kanwie zwrotu do tomizmu zaczęto obok św. Tomasza powoli interesować się także innymi myślicielami średniowiecznymi, na których uwagę zwrócili tej miary uczeni, jak: Clemens Baeumker, Heinrich Denifle op, Pierre Duhem, Franz Ehrle sı i Martin Grabmann. Ksiądz Michalski pozostawał pod urokiem prac dwóch pierwszych. Polemizował z dwoma następnymi. Wymieniał poglądy z Grabmannem i Etienne'em Gilsonem ${ }^{18}$.

„Z wyjątkiem pierwszej pracy z zakresu filozofii w Polsce - odpowiadał Michalski na ankietę przeprowadzoną w 1935 roku przez krakowski „Czas” wśród profesorów Uniwersytetu Jagiellońskiego - wszystkie niemal dalsze badania moje wyszły z podniety, jakiej doznałem jeszcze jako student w Lovanium, czytając historię mechaniki wydaną przez E. Macha i pisma P. Duhema. Najsilniej oddziałało na mnie później dzieło Duhema o Leonardzie da Vinci. Dostrzegłem wówczas, jak pomysły rodzą się i rozwijają w atmosferze duchowej, wytworzonej przez poprzedników, jak genialne umysły z czasów Odrodzenia Leonarda i Galileusza nawiązywały do tych idei, które w zarodku

${ }^{18}$ M. Kurdziałek, Udział ks. Konstantego Michalskiego i Aleksandra Birkenmajera w odkrywaniu filozofii średniowiecznej, „Studia Philosophiae Christianae” 2 (1966) nr 1, s. 85-88. 
zjawiały się zwłaszcza w szkole terministycznej już w XIV wieku. Stanęło wówczas w myśli mojej pytanie, czy także w Uniwersytecie Krakowskim byli przedstawiciele szkoły terministycznej, którzy przez ideę impetus mogli zapłodnić duszę młodego Kopernika. Doszedłszy w tym wypadku do pozytywnego wyniku - pisał dalej Michalski - zająłem się prądami krytycznymi i sceptycznymi w XIV wieku, wychodząc ciągle z założenia, że także poglądy W. Ockhama na pewno rodziły się i dojrzewały w atmosferze duchowej, stworzonej przez poprzedników. Śledziłem więc nie tyle życie filozofów, ile raczej życie idei i zagadnień, przepracowując się przez setki rękopisów w Bibliotece Jagiellońskiej i zagranicą. Po drodze tylko ustalałem różne redakcje dzieł oraz ich autentyczność. Zewnętrznymi punktami wyjścia były dla mnie zawsze Oksford i Paryż, gdyż tam w średniowieczu kiełkowały wielkie pomysły, a gdzie indziej je komentowano lub sprowadzono w zakrzepłą formę podręcznika. Ogłaszałem swe prace przeważnie po francusku w biuletynach Polskiej Akademii Umiejętności, ażeby je udostępnić za granicą" ${ }^{19}$.

\section{Metoda studium rękopisów średniowiecznych}

„Jeżeli się pragnie, żeby stare pergaminy żywym przemówiły językiem i opowiedziały nam nieznane dzieje - pisał Michalski o metodzie swojej pracy nad średniowiecznymi kodeksami, odwołując się do osiągnięć niemieckiego mediewisty Ludwiga Traubego, jednego z najlepszych ówczesnych paleografów - trzeba spełnić dwa warunki. Należy najpierw razem z tekstem badać cały kodeks, bo tam na okładkach, na marginesach, wśród wierszy, jednym słowem wszędzie, na zewnątrz i wewnątrz, znajdują się nieraz uwagi, poprawki i zapiski, w których utaiła się myśl, czekająca na swe zmartwychwstanie. Spełniwszy ten pierwszy warunek, trzeba dalej zbadać narodziny, powielanie i wędrówki kodeksów, gdyż tylko w ten sposób odkryjemy poszlaki tych szlaków, którymi się posuwały ruchy cywilizacyjne w wiekach średnich. Trzeba więc badać poszlaki wszędzie, w tekście i na okładkach, ale nie można w tych drobiazgach utonąć, trzeba mieć na oku szlaki”" ${ }^{20}$. Michalski przestrzegał mediewistów przed tym „utonięciem” w drobiazgowych badaniach szczegółowych. „Praca ciągła nad dokumentami i tekstem może tak dalece zaważyć nad umysłem badacza, że straci

${ }^{19}$ K. Michalski, Nad czym pracują przedstawiciele humanistyki, „Czas” 87 (1935) nr 176, s. 5.

${ }^{20} \mathrm{~K}$. Michalski, Filozofia wieków średnich, s. 112. 
zmysł do wielkich pytań i form ujmowania. A jednak dopiero w formułowaniu zagadnień i ich rozwiązywaniu rozpoczyna się filozoficzne myślenie”"21.

Badacz dziejów myśli średniowiecznej w jej źródłach przede wszystkim interesuje się wielkimi komentarzami, w których objaśniano Sentencje Piotra Lombarda. Przynajmniej w XIV wieku bywało tak, że bakałarz w komentarzu do pierwszej księgi Lombarda rozwijał na wstępie swe poglądy gnozeoliczne, zanim przystąpił do dowodzenia istnienia Boga, Jego jedności i Jego doskonałości. Te wykłady wstępne do każdej z czterech ksiąg Sentencji, czyli tzw. principia, stanowią dla historyka przedmiot największego zainteresowania, ponieważ w nich bakałarz poruszał często te zagadnienia, które go „najwięcej bolały”, prowadził ostre i nieraz gwałtowne dyskusje z kolegami, którzy równocześnie z nim objaśniali mistrza Lombarda. W wykładach wstępnych biło tętno współczesnej myśli teologicznej.

Najważniejszymi źródłami do poznania filozofii średniowiecznej są - zdaniem Michalskiego - komentarze do pism Arystotelesa i Sentencji Piotra Lombarda. Komentarze te występowały w podwójnej formie: pierwszą była glossa, czyli expositio, która wiernie trzymała się tekstu, zmierzając jedynie do jego wyjaśnienia, natomiast drugą były quaestiones, które dość luźno łączyły się $\mathrm{z}$ tekstem. Wśród tych ostatnich wyróżniano quaestiones litterales albo quaestiones circa litteram, w których omawiano zagadnienia związane z samym tekstem oraz quaestiones extra litteram, w których wypowiadano się z tą samą swobodą, $\mathrm{z}$ jaką występowano w czasie dysput. W tych ostatnich quaestiones wypowiadała się samodzielna myśl średniowieczna i w nich historyk znajduje obfity materiał do odtworzenia jej linii rozwojowych. Myśl ta jednak nie zawsze zachowała się w dziełach zredagowanych przez samych autorów, ale również w różnych przeróbkach. W komentarzach, podobnie zresztą jak i w innych pismach średniowiecznych, należy odróżnić: ordinatio, czyli dzieło zachowane w redakcji samego autora; reportata, czyli notatki studentów z wysłuchanych wykładów; abbreviationes, czyli skróty opracowane przez samego autora lub kogoś innego; wreszcie quaestiones pronuntiatae, czyli wykłady obcego autora spisane pod dyktando innego magistra. Największą wartość mają oczywiście komentarze w formie ordinatio i reportata. Historyk filozofii - postulował Michalski - winien opierać się, „o ile możności na ordinatio, albo przynajmniej na reportata, a nie na abbreviationes lub podejrzanej wartości pronuntiatae”. Postulat ten można jednak realizować w miarę posuwających się badań. Jeśli

${ }^{21}$ K. Michalski, Nova et vetera, Kraków 1998, s. 416. 
ślady myśli jakiegoś filozofa zachowały się tylko w formie abbreviationes lub quaestiones pronuntiatae, nie należy ich lekceważyć, lecz ogłosić z odpowiednim komentarzem ${ }^{22}$.

Michalski badał przede wszystkim procesy historyczne, rozwój prądów i zagadnień filozoficznych, a nie poszczególne gotowe już systemy, wyrwane z podłoża klimatu umysłowego, w którym wzrastały. Rozumiał, że aby być dobrym historykiem filozofii, nie wystarczy skrupulatna analiza filologiczna tekstów, ani nawet dobry węch historyka, pozwalający znajdować źródła w miejscach często dotąd nieznanych i wykrywać związki pomiędzy zagadnieniami nieraz na pozór bardzo odległymi. Posiadał umiejętność zrozumienia cudzego, nieraz całkiem odrębnego sposobu myślenia. Wiedział, że na to trzeba samemu na tyle uprawiać filozofię, żeby rozumieć problematykę filozoficzną, zarówno w ogólnych jej zarysach, wyróżniających ją od problematyki nauk szczegółowych, jak też i w treści poszczególnych pytań podstawowych, które często stanowią punkt wyjścia dla całkiem różnych poglądów, a nawet systemów filozoficznych. Krakowski uczony, stawiając jasno sformułowane pytania i widząc związki między nimi, mógł przewidywać, jak różnorodne mogą być odpowiedzi i jak one nawzajem zależą od siebie i jak w trakcie pracy badawczej nie tylko rozchodzą się drogi zmierzające do wyświetlenia tych samych zagadnień, ale też niejednokrotnie w sposób nieoczekiwany krzyżują się i schodzą ${ }^{23}$.

„Niektóre zagadnienia $\mathrm{z}$ dziejów filozofii rozjaśniają się niespodziewanie w chwili, kiedy się na nie spojrzy nie z bliska, lecz z dalszej perspektywy" - pisał Michalski z widoczną radosną pasją o swoich badaniach mediewistycznych. „Sam rozpocząłem swe badania nad filozofią średniowieczną od wieku xIV, starając się wskazać przede wszystkim wielkie drogi, którymi wówczas posuwała się myśl filozoficzna. Obok rozmaitych kierunków sceptycznych zauważyłem fideizm, który najwyraźniej płynął z dwóch źródeł, awerroizmu i materialistycznego aleksandryzmu. Od XIV wieku posunąłem się do czasów Odrodzenia, ażeby stwierdzić, że wówczas na terenie Włoch krzyżują się ze sobą w rozmaitych centrach uniwersyteckich znowu dwa fideizmy i dwa macierzyste ich prądy, awerroizm i aleksandryzm. Więcej znanym w swym rozwoju był dotąd awerroizm aniżeli aleksandryzm. Toteż było dla mnie radosną rewelacją, kiedy

${ }^{22}$ K. Michalski, Filozofia wieków średnich, s. 220-222; A. Przymusiała, O polskiej filozofii średniowiecznej na podstawie prac Konstantego Michalskiego, w: Materiały do historii filozofii średniowiecznej w Polsce, t. 2 (13), Wrocław 1970, s. 105-106.

${ }^{23}$ R. Ingarden, Uczony - filozof - człowiek, s. 568. 
mogłem sobie udowodnić, że poprzez cały XIV w. utrzymywał się w szkole terministów ten fideizm, który miał swe źródło w filozofii materialistycznej Aleksandra z Afrodyzji. Cofnąłem się wówczas wstecz do w. XIII, chcąc dotrzeć do tej zaciętej walki, która się rozegrała między łacińskimi awerroistami z jednej a św. Albertem i św. Tomaszem z drugiej strony. Nauczyłem się wówczas wysoko cenić Alberta Wielkiego, przekonawszy się, że on pierwszy dostrzegł bystrym okiem niebezpieczeństwo tkwiące w filozofii Aleksandra z Afrodyzji, choć rzadko kto wówczas o niej wspominał i wiedział. Walczył więc równocześnie Albert Wielki na dwa fronty, przeciw awerroistom i materialistycznemu aleksandryzmowi” ${ }^{24}$. Święci Albert Wielki i Tomasz z Akwinu zbudowali wielki, zwarty w sobie system metafizyczny. W tomizmie - zdaniem Michalskiego po raz pierwszy jasno i wyraźnie oddzieliła się filozofia od teologii, jako odrębna, niezależna dyscyplina ${ }^{25}$.

W dorobku naukowym Michalskiego z zakresu historii myśli średniowiecznej wyraźnie zarysowują się trzy grupy tematyczne: filozofia polska, filozofia zachodnioeuropejska i myśl filozoficzno-teologiczna Dantego.

\section{Studia nad filozofią polskiego średniowiecza}

W Polsce w Xv stuleciu mało filozofowano. Przede wszystkim uczono filozofii, korzystając z coraz bardziej skracanych podręczników. Już od wczesnego średniowiecza $\mathrm{z}$ dzieł autorów uznanych za autorytety powstawały zbiory wyciągów, które z czasem ulegały mniej lub bardziej systematycznemu opracowaniu, przyjmując zależnie od tego nazwy florilegia, catenae, sententiae lub summae. Pod koniec xv wieku w wykładach uniwersyteckich mnożyły się resumptiones, czyli powtórki, do których trzeba było zwięzłego tekstu jako podstawy. Dominujące kierunki filozoficzne formułowały swoje poglądy w oficjalnych kompendiach aprobowanych lub nawet wydawanych przez fakultety artium $^{26}$. W owym czasie szczególnym powodzeniem cieszyła się Summa naturalium przypisywana Albertowi Wielkiemu, a w każdym razie napisana w oparciu o jego komentarze do Fizyki, De coelo et mundo, De generatione et corruptione, Meteorologicorum i De anima Arystotelesa. Kompendium to bywało uzupełniane fragmentami dzieł Idziego Rzymskiego lub na różne

\footnotetext{
${ }^{24}$ K. Michalski, Filozofia wieków średnich, s. 301-302.

${ }_{25}$ K. Michalski, Filozofia wieków średnich, s. 302.

${ }^{26}$ K. Michalski, Filozofia wieków średnich, s. 104.
} 
sposoby przerabiane. W Krakowie wydawano Summa naturalium w takiej właśnie edycji przerobionej przez szkotystów ${ }^{27}$. Z biegiem czasu ustalała się konstrukcja podręczników, która - zdaniem Michalskiego - oddziaływała także na formę komentarzy. Interpretacja tego samego tekstu i ten sam zazwyczaj układ zagadnień nie zachęcały do samodzielnego myślenia, ale raczej do parafrazy starszych komentarzy, a nawet ich kopiowania. Zjawisko to obserwowano zarówno w komentarzach do pism Arystotelesa, jak i Quatuor sententiarum Piotra Lombarda. W xIV wieku, jak wspomniano wyżej bakałarz swoje własne poglądy najobszerniej rozwijał w principiach, czyli wykładach wstępnych do każdej z czterech ksiąg Sentencji. Dopiero po nich następowały objaśnienia tekstu Sentencji pisane w formie glosy, lectio, expositio albo w formie quaestiones. W xv stuleciu principia powstawały coraz częściej przez kompilowanie lub nawet kopiowanie komentarzy innych filozofów ${ }^{28}$.

Michalski, studiując w Bibliotece Jagiellońskiej zbiory średniowiecznych rękopisów, stwierdził, że osiemnaście z nich zawiera dzieła Jana Buridana, dziesięć Marsyliusza z Inghen, siedem Alberta Rickmersdorfa z Saksonii i sześć Mikołaja z Oresme. Odkrycie to stało się dla niego nader wymownym dowodem, że scholastyka krakowska pozostawała pod wyraźnym wpływem via modernorum. Wstępne badania nad wpływem szkotyzmu, tomizmu i nominalizmu na piętnastowieczną filozofię polską doprowadziło go do wniosku, że tendencje krytyczne i sceptyczne pulsujące pod powierzchnią życia umysłowego w średniowieczu wyzwolił Wilhelm Ockham przez swoją teorię powszechników i minimalistyczną teorię nauki. Zdaniem polskiego mediewisty wpływ Jana Buridana na mistrzów krakowskich słabszy w teorii poznania i metafizyce był bardzo widoczny w etyce, a zwłaszcza w filozofii przyrody. Kwestie społeczne i ekonomiczne, rozpatrywane w aspekcie etyki, dyskutowano w Krakowie najczęściej na podstawie komentarzy Buridana do Etyki nikomachejskiej i Polityki Arystotelesa. Pod ich wpływem powstały krakowskie komentarze do Etyki nikomachejskiej, zwłaszcza Pawła z Worczyna oraz cała bogata literatura o kontraktach i pobieraniu procentów (Mateusz z Krakowa, Benedykt Hesse z Krakowa i Jakub z Paradyża). Ze znacznej popularności, jaką

${ }^{27}$ Summa philosophiae naturalis Alberti Magni, Cracoviae, in officina J. Halleri, 1508; Alberti Magni philosophiae naturalis isagoge sive introductiones emendate nuper et impresse summa diligentia in libros Phisicorum. De coelo et mundo, De generatione, Meteororum, De anima Aristotelis, Cracoviae, in officina J. Halleri, 1516.

${ }^{28}$ K. Michalski, Filozofia wieków średnich, s. 122-123; A. Przymusiała, O polskiej filozofii średniowiecznej..., s. 107-108. 
cieszył się Buridan i jego zwolennicy w Krakowie, można było wnosić, że głoszone przez nich idee wywarły wpływ na myślenie Kopernika, który mógł pod ich wpływem kształtować swoje myślenie w zakresie astronomii. W drugiej połowie xIv, a zwłaszcza pod koniec xv stulecia tryumfowała pod Wawelem via antiqua zasilona elementami szkotyzmu przyniesionymi z Paryża przez Michała z Biestrzykowa. Równocześnie ożywił się nieco tomizm, kształtujący się pod wpływem kolońskiego sporu między albertystami i tomistami ${ }^{29}$. W drugiej połowie $\mathrm{xv}$ wieku pod wpływem devotio moderna następowały odwrót od spekulacji i zwrócenie się ku życiu wewnętrznemu, mistyce i silniejszemu dążeniu do reformy życia kościelnego.

\section{Badania dziejów średniowiecznej filozofii zachodnioeuropejskiej}

Michalski w swoich badaniach doszedł do wniosku, że dogłębne poznanie prądów doktrynalnych w polskiej filozofii średniowiecznej jest możliwe dopiero po uprzednim zaznajomieniu się z głównymi nurtami myślowymi Zachodu. Od 1920 roku poniechał niemal całkowicie dalszych badań źródłowych nad scholastyką polską. Przeszedł do poszukiwania jej źródeł i podjął studia nad głównymi prądami filozofii zachodnioeuropejskiej xIV stulecia. W swych badaniach interesował się nie szkołami, nie systemami filozoficznymi, ale przede wszystkim zagadnieniami podejmowanymi w XIV wieku, ich sformułowaniami oraz proponowanymi dla nich rozwiązaniami. Jako wychowanek szkoły lowańskiej, szczególnie interesował się zagadnieniami teoriopoznawczymi i w tym aspekcie badał czternastowieczne życie umysłowe Paryża i Oksfordu. W rezultacie zarysował przedstawiony poniżej obraz filozofii xIV wieku. Najwybitniejsze umysły owego stulecia skupiły się pod sztandarem nominalizmu. Zaczął się on wprawdzie w Paryżu, ale dzięki Ockhamowi i jego uczniom szybciej i pełniej rozwinął się w Oksfordzie, aby stamtąd w sposób istotny znowu oddziałać na Paryż. Nominalizm w dużej mierze przyczynił się do wzmożenia krytycyzmu i sceptycyzmu, pośrednio także fideizmu. Nie był

${ }^{29}$ K. Michalski, Filozofia wieków średnich, s. 98-99; M. Markowski, Burydanizm w Polsce $w$ okresie przedkopernikańskim, Wrocław 1971, s. 20-22; M. Kurdziałek, Trwałość osiagnięć księdza profesora Konstantego Michalskiego jako historyka filozofi średniowiecznej, „Analecta Cracoviensia” 12 (1980), s. 46; S. Piech, Księdza Konstantego Michalskiego życie i dzieło, „Folia Historica Cracoviensia" 4-5 (1997-1998), s. 261-277. 
jednak przyczyną powstania tych prądów myślowych. Wyrosły one z augustynizmu głoszącego zwodniczość poznania zmysłowego i konieczność oświecenia Bożego nawet w poznaniu naturalnym; z filozofii arabskiej, zwłaszcza $\mathrm{z}$ antyfilozoficznych poglądów Algazela i mottekaleminów; $\mathrm{z}$ materializmu psychologicznego Aleksandra z Afrodyzji; z awerroistycznej teorii podwójnej prawdy; z wprowadzonego przez Dunsa Szkota rozróżnienia pomiędzy wiedzami abstrakcyjną i intuicyjną; $z$ arystotelesowskiego wyodrębnienia dwóch sposobów dowodzenia: naukowego i dialektycznego. Synteza przedstawiona przez Michalskiego do dziś nie straciła na swej aktualności ${ }^{30}$. Wysuwane dotychczas zastrzeżenia, korekty i uzupełnienia - zdaniem ks. Mariana Kurdziałka - nie tylko nie podważają trwałości i wartości osiągnięć tego historyka filozofii, ale jeszcze bardziej je podkreślają ${ }^{31}$.

Na podstawie rękopisów autorów mało znanych i wcale do jego czasów nieznanych wykazał, że ci dotychczas znani autorzy stanowili jedynie cząstkę wielkiego i różnorodnego obozu „modernistów” xıv wieku. Ockham nie był zjawiskiem odosobnionym, lecz ogniwem w łańcuchu. Michalski wykazał dobitniej niż to uczynili wcześniejsi mediewiści, że ruch modernistyczny nie był dziełem przypadku, lecz był dawno przygotowywany. Zarodki jego można było spotkać już w XIII stuleciu, klasycznym okresie scholastyki. Michalski dowiódł, że miał on swoje źródła nie tylko w awerroizmie z jego teorią podwójnej prawdy i w szkotyzmie ograniczającym znacznie kompetencje rozumu, ale także w augustynizmie, który teorią iluminacji podważał zaufanie do rozumu, a nawet $\mathrm{w}$ logice Arystotelesa $\mathrm{z}$ jego teorii rozumowania prawdopodobnego zawartej w Topikach. Trafnie scharakteryzował filozofię XIV wieku, wysuwając na pierwszy plan jej krytycyzm i sceptycyzm, a nie nominalizm, jak to zazwyczaj dawniej praktykowano. Krytycyzm ówczesny zasadzał się przede wszystkim na analizie pewności sądów, odróżnianiu stopni pewności i prawdopodobieństwa. Sceptycyzm zaś skierowany był przeciw próbom racjonalnego uzasadnienia dogmatów wiary. Michalski wyróżnił zasadnicze typy filozofii xıv wieku. Przedstawił kierunki jej rozwoju. Głównymi ośrodkami filozofii były wówczas Oksford i Paryż. Filozofia modernistów była uprawiana jednocześnie w obydwóch ośrodkach od początku stulecia. W Oksfordzie miała ona charakter psychologistyczny, zaś w Paryżu idealistyczny. Prąd oksfordzki, wydawszy Ockhama,

${ }^{30}$ M. Kurdziałek, Trwałość osiagnięć księdza profesora Konstantego Michalskiego..., s. 52-53; M. Kurdziałek, Udział ks. Konstantego Michalskiego..., s. 102-103.

${ }^{31}$ M. Kurdziałek, Trwałość osiągnięć księdza profesora Konstantego Michalskiego..., s. 52-53. 
wszedł w swojej ojczyźnie w okres stagnacji, natomiast opanował Paryż, który na długo stał się centrum ockhamizmu. Michalski na naczelne miejsce w dziejach scholastyki wysunął ockhamistę Jana z Mirecourt, który po Ockhamie miał najbardziej samodzielne i ważne pomysły w dziedzinie teorii poznania.

Poza wymienionymi wyżej kwestiami ogólniejszego znaczenia krakowski uczony zajmował się również nie mniej ważnymi sprawami szczegółowymi. Wyjaśnił ważne, a przez historyków źle rozumiane rozróżnienie ens subiectivum i ens obiectivum. Uważano, że od średniowiecza terminy te zmieniły swoje znaczenie, tymczasem przekonaniae to nie było słuszne. Przemiana terminologii polegała raczej na tym, że zatarła się różnica pomiędzy bytem obiektywnym a realnym. Michalski w trakcie swoich badań uzupełnił sporządzony przez Duhema wykaz ockhamistów, którzy wyznawali teorię impetu. Wykazał, że wcześniejszym od Jana Buriana badaczem na tym polu był Franciszek de Marchia ${ }^{32}$.

Michalski był „najwybitniejszym, jak dotąd polskim historykiem filozofii, zarazem pierwszym w Polsce uczonym, który badania w zakresie historii filozofii postawił na prawdziwie europejskim poziomie, sięgając wprost do źródeł i prowadząc studia samodzielnie na odcinkach przed nim mało zbadanych lub zgoła nieznanych - pisał po jego śmierci Roman Ingarden. Był zarazem pierwszym uczonym polskim, który pracując nad wyjaśnieniem głównych prądów w filozofii późniejszego średniowiecza na terenie Francji i Anglii w wieku xIV, wniósł $\mathrm{w}$ tej dziedzinie trwały i istotny dorobek w naukę europejską. Był też w nauce zagranicznej powszechnie znany i wysoko ceniony, a podobnie w Polsce wielce go poważano"33. W bibliotekach polskich, angielskich, francuskich, niemieckich i włoskich przebadał pod względem historyczno-krytycznym ponad 360 rękopisów filozoficznych. Oparte na tych badaniach prace, szczególnie: Les courants philosophíques à Oxford et à Paris pendant le XIV ${ }^{e}$ siècle ${ }^{34}$; Le criticisme et la scepticisme dans la philosophie du XIV $V^{e}$ siècle ${ }^{35}$; Les courants critiques

${ }^{2}$ W. Tatarkiewicz, Prace x. Konstantego Michalskiego o filozofii XIV wieku, „Przegląd Filozoficzny” 30 (1927) z. 1, s. 96; toż w: K. Michalski, Dilatatio corde, s. 560-561.

${ }^{33}$ R. Ingarden, Uczony - filozof - człowiek, s. 567.

34 „Bulletin International de l'Académie Polonaise des Sciences et des Lettres, Classe d'Histoire et de Philosophie" 1919, 1920, s. 59-88; toż w: K. Michalski, Histoire de la philosophie, Kraków 1999, s. 12-34.

35 „Bulletin International de l'Académie Polonaise des Sciences et des Lettres, Classe d'Histoire et de Philosophie" 1925 nr 1-10, s. 41-122. Osob. odb. Kraków 1926; toż w: K. Michalski, Histoire de la philosophie, s. 96-156. 
et sceptiques dans la philosophie du XIV $V^{e_{36}}$; La physique nouvelle et des différents courants philosophiques au XIV ${ }^{e}$ siècle ${ }^{37}$; Wpływ Oksfordu na filozofię Jana $z$ Mírecourt $^{38}$; Les sources du criticisme et du scepticisme dans la philosophie $d u X I V^{e}$ siècle $^{39}$; Odrodzenie nominalizmu w XIV wieku ${ }^{40}$; La problème de la volonté à Oxford et à Paris au XI ${ }^{\text {ve }}$ siècle ${ }^{41}$ uczyniły z Michalskiego - zdaniem Władysława Tatarkiewicza - ,jeden z wielkich autorytetów światowych w rzeczach filozofii średniowiecznej, jednego z paru historyków, którzy zmienili pogląd na koleje myśli europejskiej, pokazali, że zapoznawany dotąd wiek XIV dał początek ideom nowożytnym"42. Michalski wszedł na rozległe i mało znane pola filozofii terministycznej xIV stulecia i wykazał, że przedstawiciele via nova zajmowali krytyczną postawę $\mathrm{w}$ odniesieniu do dorobku myślicieli xıI stulecia, czyli via antiqua. Udowodnił, że czternastowieczna filozofia nowej szkoły stanowiła ważne ogniwo w łańcuchu przemian prowadzących od średniowiecza do narodzin myśli nowożytnej. Wskazał na wiele zbieżności problemowo-doktrynalnych, analogii i pokrewieństw występujących pomiędzy filozofią średniowieczną a nowożytną i współczesną. Pod wpływem filozofii wartości Maxa Schelera poszukiwał w filozofii xıv wieku problemu roli poznawczej woli. Logika trójwartościowa Jana Łukasiewicza skłoniła go do szukania u terministów XIV stulecia trzeciej wartości logicznej, różnej od prawdy i fałszu. Zauważył, że idea tej trzeciej wartości logicznej występowała już

36 „Bulletin International de l'Académie Polonaise des Sciences et des Lettres, Classe d'Histoire et de Philosophie” 1925 nr 1-10, s. 192-242. Osob. odb. Kraków 1927; toż w: K. Michalski, Histoire de la philosophie, s. 157-196.

37 „Bulletin International de l'Académie Polonaise des Sciences et des Lettres, Classe d'Histoire et de Philosophie" 1927 nr 4-6, s. 93-164. Osob. odb. Kraków 1928; toż w: K. Michalski, Histoire de la philosophie, s. 198-248.

${ }^{38}$ „Rozprawy Polskiej Akademii Umiejętności. Wydział Historyczno-Filozoficzny”, t. 38. (Ogólnego zbioru t. 63, Kraków 1921, s. 1-74). Osob. odb. Kraków 1921; toż w: K. Michalski, Filozofia wieków średnich, s. 142-206.

39 W: La Pologne au $V^{\mathrm{e}}$ Congres International des Sciences Historiques, Bruxelles 1923, Varsovie 1924, s. 241-268. Streszczenie w osobnej odbitce. Cracovie 1924, s. 1-28; toż w: K. Michalski, Histoire de la philosophie, s. 36-58.

40 „Kwartalnik Filozoficzny” 4 (1926), s. 171-216, 477-496; toż w: K. Michalski, Filozofia wieków średnich, s. 232-276.

${ }^{41}$ Studia Philosophica, t. 2, Leopoli 1937, s. 233-364. Osob. odb. Leopoli 1937; toż w: K. Michalski, Histoire de la philosophie, s. 318-411.

${ }^{42}$ W. Tatarkiewicz, Filozofia $w$ Uniwersytecie Jagiellońskim od XVII do połowy xx wieku, w: Studia z dziejów Wydziału Filozoficzno-Historycznego Uniwersytetu Jagiellońskiego, red. S. Mikucki, Kraków 1967, s. 33-34. 
u Dunsa Szkota, Wilhelma Ockhama, a zwłaszcza u Piotra z Auriole. Dążenie do odkrywania tego rodzaju związków miało swoje główne źródło w jego umysłowości. Przez całe życie pozostawał myślicielem na wskroś współczesnym. Szedł za śladami myśli nowożytnej i jakby nieopatrznie wstąpił na teren filozofii średniowiecznej. Kiedy zaś znalazł się w kręgu jej oddziaływania, podobnie jak Désiré Mercier, Jacques Maritain, Étienne Gilson, nie potrafił czy już nie chciał się z niej wyzwolić. Fascynowała go nowożytność, bogactwo i urok ciągłych spotkań z „nieznanym”. Coraz głębiej wchodził w gąszcz źródeł, problemów, doktryn i prądów myślowych. Wskazywał łączące je więzy. Przez swoje badania przyczynił się $\mathrm{w}$ większym stopniu niż inni mediewiści do rozproszenia resztek zadawnionych, uporczywie powtarzanych, krzywdzących scholastykę opinii $^{43}$. Badania średniowiecznych manuskryptów uczyniły go sławnym, ale niestety bezpowrotnie zniszczyły jego oczy.

\section{Fascynacja myślą filozoficzno-teologiczną Dantego Alighieri}

Osobną grupę tematyczną mediewistycznych zainteresowań Michalskiego stanowiły jego studia dantejskie, którymi zajmował się przez ostatnie 26 lat swojego życia. „Dla Dantego - jego zdaniem - filozofia nie była dziedziną oderwanych od życia spekulacji, lecz z tym życiem jak najściślej się łączyła, tłumaczyła jego zagadnienia, wskazywała ostateczny cel, określała człowiekowi jego w wszechświecie stanowisko"44. Pasjonującej go myśli filozoficzno-teologicznej Dantego poświęcił rozprawy: Mistyka i scholastyka u Dantego ${ }^{45}$; Myśl franciszkańska i jej wpływ na Dantego ${ }^{46}$; Eros i Logos u Dantego ${ }^{47}$; La gnoséologiae

${ }^{43}$ M. Kurdziałek, Udział ks. Konstantego Michalskiego..., s. 104; S. Piech, Wkład Ks. Konstantego Michalskiego do skarbca kultury europejskiej, „Fides, Ratio, et Patria. Studia Toruńskie” 6 (2017), s. 30-46.

${ }^{44}$ K. Michalski, Mistyka i scholastyka u Dantego, „Miesięcznik Katechetyczny i Wychowawczy” 10 (1921), s. 258.

45 „Miesięcznik Katechetyczny i Wychowawczy” 10 (1921), s. 257-290; 11 (1922), s. 14-23; toż w: K. Michalski, Filozofia wieków średnich, s. 461-492.

${ }^{46}$ „Przegląd Współczesny” 6 (1927) t. 20, s. 11-29; toż w: K. Michalski, Filozofia wieków średnich, s. 493-513.

47 „Przegląd Powszechny” 52 (1935) t. 108, s. 149-170, 279-302; 53 (1936) t. 209, s. 152-172; toż w: K. Michalski, Filozofia wieków średnich, s. 514-557. 
de Dante ${ }^{48}$. „Cała twórczość Dantego wskazuje - pisał Michalski - że zagadnienia etyczne wchodziły w krąg jego najżywszych interesów, cała zaś Boska komedia tworzy niezbity dowód, że pierwiastek moralny złączył się u niego jak najściślej z pierwiastkiem religijnym, że z niego czerpał swą inspirację i siłę". Dusza poety-filozofa najpełniej wypowiedziała się w Boskiej komedii. „Potrójna idea wyzwolenia duszy ze zła, wewnętrznego jej oświecenia i zjednoczenia z Bogiem tworzy oś poematu, około której układają się wszystkie inne myśli”"49. Podobnie zapatrywał się na tę sprawę Etienne Gilson ${ }^{50}$. Polski mediewista, częściowo zgadzając się z Pierrem Mandonnetem ${ }^{51}$, sądził, że Beatrycze jest postacią historyczną, która w Boskiej komedii stała się symbolem łaski uświęcającej, łącznie z cnotami teologicznymi.

Michalski, studiując gnozeologię Dantego, doszedł do wniosku, że „Dante wszedł na drogę, która na końcu XIII w. i na początku XIV w. poprowadziła do krytycyzmu i fideizmu"s2. Od początku XIV wieku pod wpływem wzmagającego się krytycyzmu przenoszono cały szereg tez $\mathrm{z}$ dziedziny filozofii do dziedziny wiary. Michalski zauważył ten proces już u Dantego, u którego zagadnienia nieśmiertelności duszy i wolności woli należą raczej do dziedziny wiary niż do filozofii. Zdaniem polskiego uczonego również pojęcia materii pierwszej, wieczności i w ogóle cała teodycea należą u Dantego do dziedziny wiary. Michalski w tekstach Dantego, w przeciwieństwie do Gilsona, doszukiwał się fideizmu, którego źródła upatrywał bądź to w myśli Ryszarda ze św. Wiktora, bądź w prądach umysłowych tamtego okresu. Pozostawał pod przemożnym wpływem pism św. Alberta Wielkiego ${ }^{53}$. Nie można zrozumieć Boskiej komedii bez poznania ducha mistyki średniowiecznej. Dantego „najsilniej natchnęły" Itinerarium mentis in Deum św. Bonawentury oraz Beniamin minor i Beniamin maior Ryszarda ze św. Wiktora ${ }^{54}$.

${ }^{48}$ Kraków 1950; toż w: K. Michalski, Histoire de la philosophie, s. 412-465; toż w: K. Michalski, Filozofia wieków średnich, s. 566-616.

49 K. Michalski, Mistyka i scholastyka..., s. 259.

${ }^{50}$ E. Gilson, Dante et la philosophie, Paris 1939, s. 100-113.

${ }^{51}$ P. Mandonnet, Dante le theologien, Paris 1935, s. 37.

${ }^{52}$ K. Michalski, Filozofia wieków średnich, s. 563.

${ }^{53}$ K. Kłósak, Twórczość naukowa ks. Konstantego Michalskiego CM, w: K. Michalski, Dilatatio corde, s. 590-591; W. Paluchowski, Filozofia człowieka u Dantego. Próba rekonstrukcji na podstawie pism Konstantego Michalskiego, Kraków 200o, s. 142-178; A. Usowicz, Zbieracze złotych kłosów, s. 489-49o.

${ }^{54}$ K. Michalski, Filozofia wieków średnich, s. 465-466, 606-610. 


\section{Corpus Philosophorum Medii Aevii}

Badanie nurtów myślowych XIV wieku i problemów filozofii scholastycznej utwierdziły Michalskiego w przekonaniu, że dynamika średniowiecznego życia umysłowego była ściśle związana z recepcją dzieł Arystotelesa i ich arabskich i greckich komentatorów. Filozofowie średniowieczni formowali swoje poglądy najczęściej w związku z lekturą pism Arystotelesa, Awicenny, Awerroesa lub Aleksandra z Afrodyzji, które czytali w różnych wersjach łacińskich. Jedne były przekładami z języka greckiego, inne zaś z arabskiego. Poszczególne tłumaczenia nieraz bardzo różniły się między sobą, i to w ważnych doktrynalnie zagadnieniach. W miarę krytyczna edycja owych łacińskich wersji dawałaby klucz do zrozumienia różnic słownych, pojęciowych, a nawet rzeczowych występujących w interpretacjach mistrzów średniowiecznych czytających pisma tych samych filozofów greckich lub arabskich. Z tych przemyśleń Michalskiego przy współudziale swego przyjaciela Aleksandra Birkenmajera, który już od lat badał łacińskie przekłady pism Arystotelesa i jego greckich i arabskich komentatorów, zrodził się projekt krytycznego wydania średniowiecznych łacińskich przekładów Arystotelesa, łacińskich tłumaczeń myślicieli arabskich i żydowskich i co celniejszych średniowiecznych komentarzy do dzieł Stagiryty oraz samodzielnych traktatów filozoficznych. Projekt serii wydawniczej Corpus Phílosophorum Medii Aevii Michalski przedłożył w 1928 roku w imieniu Polskiej Akademii Umiejętności obradującej w Brukseli Union Académique Internationale, która w 1930 roku przyjęła propozycję obydwóch mediewistów krakowskich ${ }^{55}$. W ramach Unii powołano specjalną komisję do opracowania i wydania Aristoteles Latinus. W skład komisji, na czele której stanął Michalski, wchodzili James Houston Baxter (St Andrews University), Lluis Nicolau d'Olver (Institut d'Estudis Catalans), Vinzenzo Ussani (Università di Roma) i George Lacombe (Catholic University of America). W 1939 roku ukazał się w Rzymie pierwszy tom Aristoteles Latinus ${ }^{56}$. Polski uczony nadał badaniom nad arystotelizmem podejmowanym przez światową mediewistykę taki rozmach, że trwają one po dzień dzisiejszy. Zainicjowany przez niego Corpus Philosophorum Medii Aevii stanowi najtrwalszy i największy wkład

${ }_{55}$ M. Kurdziałek, Udziat ks. Konstantego Michalskiego..., s. 93-99.

${ }^{56}$ Aristoteles Latinus, codices. Descripsit G. Lacombe in societatem operis adsumptis A. Birkenmajer, M. Dulong, Aet. Franceschini, pars 1, Roma 1939. 
do badań nad myślą średniowieczną, kontynuowanych przez ośrodki naukowe w Polsce i zagranicą ${ }^{57}$.

\section{Trwałość osiągnięć mediewistycznych Konstantego Michalskiego}

Prace ks. Michalskiego - według Francesca Corvina, profesora Uniwersytetu w Mediolanie, wybitnego znawcy filozofii xIV stulecia - przyczyniły się nie tylko do poznania prądów filozoficznych i ich przedstawicieli pozostających dotąd w cieniu, ale też - co najważniejsze - do ukazania głęboko sięgającej perspektywy i dalekiego horyzontu, w jakich należało badać dzieje myśli średniowiecznej ${ }^{58}$. W rozprawach polskiego badacza, w przeciwieństwie do dotychczasowego pojmowania dziejów myśli wieków średnich, historia ta nie przedstawiała jakiegoś „spoistego frontu ani jednolitej harmonii”, lecz prezentowała różnorodność prądów filozoficznych, niekiedy nawet wprost sobie przeciwstawnych. „Tłum rzekomo bezwartościowych epigonów żyjących w XIV wieku - pisał dalej Corvino - przemienia się u Michalskiego w zastęp oryginalnych myślicieli, którzy nie gubią się w problemach drugorzędnych i w drobnostkach sofistycznych, lecz podejmują wielkie problemy filozoficzne; nie podążają niewolniczo za myślą twórców wielkich systemów filozoficznych, przeciwnie, wstrząsają podwalinami ogólnie i często bezkrytycznie uznanymi" 59 . Przedstawienie takiego obrazu czternastowiecznej filozofii zachodnioeuropejskiej było owocem ciężkiej pracy, jaką było przestudiowanie przez krakowskiego profesora ponad 360 rękopisów, w których łatwo mógł pogrążyć się w zbyt drobiazgowych erudycyjnych analizach paleograficznych i filologicznych. Uniknął jednak tego niebezpieczeństwa, podobnie jak i pokusy odnajdywania za wszelką cenę w każdym dziele i u każdego autora tendencji „krytycznych” i „sceptycznych”. Włoski mediewista, podkreślając osiągnięcia naukowe Michalskiego, pisał, że dzięki niemu „poznaliśmy nazwiska i myśli filozofów, którzy przedtem byli nieznani, poznaliśmy również nie wydane dzieła autorów znanych, odkryliśmy postawę i orientację myśli średniowiecznej, otwarła się nam droga do nowej

57 M. Markowski, Konstanty Michalski..., s. 9-11; M. Markowski, Konstanty Michalski projektodawca "Aristoteles Latinus”, w: Pogladdy filozoficzne Konstantego Michalskiego. Materiały pokonferencyjne przygotowane pod red. C. Głombika, Katowice 1999, s. 53-61.

${ }^{58}$ F. Corvino, Ks. dr Konstanty Michalski (1879-1947), „Poradnik Kulturalno-Oświatowy” (Londyn) 19 (1959) $\mathrm{nr}$ 212, s. 32.

59 F. Corvino, Ks. dr Konstanty Michalski (1879-1947), s. 33. 
interpretacji całej epoki historii filozofii. [...]. Prace Michalskiego mają stale podwójną wartość - konkludował Corvino - dają przede wszystkim dokładne wiadomości analityczne, na których można polegać, ponadto dają obraz całości, perspektywę historyczną, w której występują wyraźnie poszczególni myśliciele i poszczególne prądy" ".o . Rozprawy Michalskiego często służyły późniejszym mediewistom jako punkt wyjścia dla ich własnych badań. „Bez przesady można powiedzieć - pisał Corvino w 1959 roku - że wszystkie rozprawy nad filozofią XIV wieku wykonane $\mathrm{w}$ ostatnich trzydziestu latach wyrosły z tych właśnie prac Michalskiego" ${ }^{61}$.

Do rozpraw mediewistycznych krakowskiego uczonego, mimo upływu czasu nadal sięgają współcześni badacze kultury umysłowej wieków średnich. Filozof ten bowiem przemyśleniami swoimi skierował późniejszą polską mediewistykę powojenną ku badaniom źródłowym i analizie zagadnień filozoficznych $^{62}$. Na trwałe wszedł do fundamentalnych podręczników filozofii średniowiecznej. Warto wspomnieć chociażby te, które opracowali Bernhard Geyer $^{63}$, Étienne Gilson ${ }^{64}$, Kurt Flasch ${ }^{65}$ i Władysław Tatarkiewicz ${ }^{66}$. Jubileusz 6oo-lecia Wydziału Teologii w Krakowie (1397-1997) dał impuls do zebrania prac mediewistycznych Michalskiego rozproszonych w licznych, nieraz trudno już dostępnych czasopismach i opracowaniach zbiorowych, uporządkowania ich pod względem tematycznym i wydania w serii Studia do Dziejów Wydziału Teologicznego Uniwersytetu Jagiellońskiego w dwóch tomach: Filozofia wieków średnich (Kraków 1997); Histoire de la philosophie (Kraków 1999). Wydawnictwo to niezmiernie ułatwia współczesną refleksję nad osiągnięciami Michalskiego w zakresie badań nad dziejami filozofii wieków średnich.

F. Corvino, Ks. dr Konstanty Michalski (1879-1947), s. 33.

${ }^{61}$ F. Corvino, Ks. dr Konstanty Michalski (1879-1947), s. 33.

${ }^{62}$ M. Markowski, Wstęp, w: K. Michalski, Filozofia wieków średnich, s. 11.

${ }_{63}$ B. Geyer, Die patristische und scholastische Philosophie, Basel-Stuttgart $1958^{13}$.

${ }^{64}$ E. Gilson, History of Christian Philosophy in the Middle Ages, New York 1955, w tłumaczeniu polskim: Historia filozofii chrześcijańskiej w wiekach średnich, Warszawa 1966;1987².

${ }^{65}$ K. Flasch, Das philosophische Denken im Mittelalter. Von Augustin zu Machiavelli, Stuttgart 1986.

${ }^{66}$ W. Tatarkiewicz, Historia filozofii, t. 1-3, Lwów 1931; Warszawa 1999 ${ }^{17}$. 


\section{Bibliografia}

Alberti Magni philosophiae naturalis isagoge sive introductiones emendate nuper et impresse summa diligentia in libros Phisicorum. De coelo et mundo, De generatione, Meteororum, De anima Aristotelis, Cracoviae, in officina J. Halleri, 1516. Archiwum Akt Nowych w Warszawie, sygn. Mwriop 4359, Ministerstwo Wyznań Religijnych i Oświecenia Publicznego do ks. K. Michalskiego, [b.d.] XI 1937. Archiwum Komisji do Badania Historii Filozofii w Polsce, t. 1, cz. 1, Kraków 1915. Osob. odb. Kraków 1914.

Archiwum Uniwersytetu Jagiellońskiego, sygn. S II 619, Życiorys. Aristoteles Latinus, codices. Descripsit G. Lacombe in societatem operis adsumptis A. Birkenmajer, M. Dulong, Aet. Franceschini, pars 1, Roma 1939. Archiwum Uniwersytetu Jagiellońskiego, sygn. S II 619, Ministerstwo Wyznań Religijnych i Oświecenia Publicznego do Rektoratu UJ, Warszawa 7.09.1921. Archiwum Uniwersytetu Jagiellońskiego, sygn. S II 619, Ministerstwo Wyznań Religijnych i Oświecenia Publicznego do Wydz. Teolog. UJ, Warszawa 27.06.1919. Archiwum Uniwersytetu Jagiellońskiego, sygn. S II 987, Wielka kronika uJ, Rękopisy i notaty $1914-1925$.

Corvino F., Ks. dr Konstanty Michalski (1879-1947), „Poradnik Kulturalno-Oświatowy" (Londyn) 19 (1959) nr 212, s. 32-35.

Flasch K., Das philosophische Denken im Mittelalter. Von Augustin zu Machiavelli, Stuttgart 1986.

Geyer B., Die patristische und scholastische Philosophie, Basel-Stuttgart $1958^{13}$.

Gilson E., History of Christian Philosophy in the Middle Ages, New York 1955, w tłumaczeniu polskim: Historia filozofii chrześcijańskiej w wiekach średnich, Warszawa 1966, $1987^{2}$.

Gilson E., Dante et la philosophie, Paris 1939.

Ingarden R., Uczony - filozof - człowiek, w: K. Michalski, Dilatato corde, Kraków 2002, s. 566-570.

Kłósak K., Twórczość naukowa ks. Konstantego Michalskiego CM, w: K. Michalski, Dilatatio corde, Kraków 2002, s. 590-591.

Kurdziałek M., Trwałość osiagnięć księdza profesora Konstantego Michalskiego jako historyka filozofi średniowiecznej, „Analecta Cracoviensia” 12 (1980), s. 45-55. Kurdziałek M., Udział ks. Konstantego Michalskiego i Aleksandra Birkenmajera w odkrywaniu filozofii średniowiecznej, "Studia Philosophiae Christianae” 2 (1966) $\mathrm{nr}$ 1, s. 85-88.

Mandonnet P., Dante le theologien, Paris 1935. 
Markowski M., Burydanizm w Polsce w okresie przedkopernikańskim, Wrocław 1971. Markowski M., Konstanty Michalski (I879-1947), „Studia Mediewistyczne” 26 (1989) z. 1, s. 8.

Markowski M., Konstanty Michalski projektodawca „Aristoteles Latinus”, w: Poglady filozoficzne Konstantego Michalskiego. Materiały pokonferencyjne przygotowane pod red. C. Głombika, Katowice 1999, s. 53-61.

Michalski K., Filozofia wieków średnich, Kraków 1997.

Michalski K., Histoire de la philosophie, Kraków 1999.

Michalski K., Mistyka i scholastyka u Dantego, „Miesięcznik Katechetyczny i Wychowawczy" 10 (1921), s. 257-290; 11 (1922), s. 14-23.

Michalski K., Nad czym pracuja przedstawiciele humanistyki, „Czas” 87 (1935) nr 176, s. 5 .

Michalski K., Nova et vetera, Kraków 1998.

Morstin-Górska M., Przyjaciel serc ludzkich, w: 70 Żywotów, wybór i red. A. Paluchowski, Kraków 1977, s. 221.

Nieciowa E., Członkowie Akademii Umiejętności oraz Polskiej Akademii Umiejętności 1872-1952, Wrocław-Kraków 1973.

Paluchowski W., Filozofia człowieka u Dantego. Próba rekonstrukcji na podstawie pism Konstantego Michalskiego, Kraków 2000.

Piech S., Dzieje Wydziału Teologicznego Uniwersytetu Jagiellońskiego w latach 1880-1939, Kraków 1995.

Piech S., Konstanty Józef Michalski (1879-1947), w: Złota Księga Papieskiej Akademii Teologicznej, red. S. Piech, Kraków 2000, s. 435-436.

Piech S., Księdza Konstantego Michalskiego życie i dzieło, „Folia Historica Cracoviensia" 4-5 (1997-1998), s. 261-277.

Piech S., Michalski Konstanty Józef, w: Encyklopedia filozofii polskiej, red. A. Maryniarczyk, t. 2, Lublin 2011, s. 134-135.

Piech S., W cieniu kościołów i synagog. Życie religijne międzywojennego Krakowa 1918-1939, Kraków 1999.

Piech S., Wkład Ks. Konstantego Michalskiego do skarbca kultury europejskiej „Fides, Ratio, et Patria. Studia Toruńskie" 6 (2017), s. 30-46.

La Pologne au Ve Congres International des Sciences Historiques, Bruxelles 1923, Varsovie 1924. Osob. odb. Cracovie 1924; toż w: Michalski K., Histoire de la philosophie, Kraków 1999, s. 36-58.

Przymusiała A., O polskiej filozofi średniowiecznej na podstawie prac Konstantego Michalskiego (Materiały do Historii Filozofii Średniowiecznej w Polsce 2 [13]), Wrocław 1970, s. 105-106. 
Summa philosophiae naturalis Alberti Magni, Cracoviae, in officina J. Halleri, 1508. Tatarkiewicz W., Filozofia $w$ Uniwersytecie Jagiellońskim od XVII do połowy Xx wieku, w: Studia $z$ dziejów Wydziału Filozoficzno-Historycznego Uniwersytetu Jagiellońskiego, red. S. Mikucki, Kraków 1967, s. 33-34.

Tatarkiewicz W., Historia filozofii, t. 1-3, Lwów 1931; Warszawa $1999^{17}$.

Tatarkiewicz W., Prace x. Konstantego Michalskiego o filozofii XIV wieku, „Przegląd Filozoficzny" 30 (1927) z. 1, s. 96; toż w: Michalski K., Dilatatio corde, Kraków 2002, s. 560-561.

Usowicz A., Kłósak K., Ksiądz Konstanty Michalski (I879-1947), Kraków 1949. Usowicz A., Zbieracze złotych kłosów, Kraków 2012.

\section{Streszczenie}

Ksiądz Konstanty Michalski CM (1879-1947), filozof, historyk filozofii, profesor i rektor Uniwersytetu Jagiellońskiego, członek czynny Wydziału HistorycznoFilozoficznego Polskiej Akademii Umiejętności był przewodniczącym jej Komisji Historii Filozofii w Polsce i wicedyrektorem Wydziału Historyczno-Filozoficznego. Przeżył gehennę więźnia niemieckiego obozu koncentracyjnego w Sachsenhausen koło Berlina. W dorobku naukowym Michalskiego w zakresie historii myśli średniowiecznej wyraźnie zarysowują się trzy grupy tematyczne: filozofia polska, filozofia zachodnioeuropejska i myśl filozoficzno-teologiczna Dantego Alighieri. Badania nurtów myślowych xIV wieku i problemów filozofii scholastycznej upewniły Michalskiego w przekonaniu, że dynamika średniowiecznego życia umysłowego była ściśle związana z recepcją dzieł Arystotelesa i ich arabskich i greckich komentatorów. Wraz z Aleksandrem Birkenmajerem wysunął projekt krytycznego wydania średniowiecznych łacińskich przekładów Arystotelesa, łacińskich tłumaczeń myślicieli arabskich i żydowskich i najlepszych średniowiecznych komentarzy do dzieł Stagiryty oraz samodzielnych traktatów filozoficznych. Projekt serii wydawniczej Corpus Phílosophorum Medii Aevii Michalski przedłożył w 1928 roku w imieniu Polskiej Akademii Umiejętności obradującej w Brukseli Union Académique International, która w 1930 roku przyjęła propozycję obydwóch mediewistów krakowskich. Michalski nadał badaniom nad arystotelizmem podejmowanym przez światową mediewistykę taki rozmach, że trwają one po dzień dzisiejszy. Zainicjowany przez niego Corpus Philosophorum Medii Aevii stanowi najtrwalszy i największy wkład do badań nad myślą średniowieczną, kontynuowanych przez ośrodki naukowe w Polsce i zagranicą. Michalski w swoich badaniach doszedł 
do wniosku, że dogłębne poznanie prądów doktrynalnych w polskiej filozofii średniowiecznej jest możliwe dopiero po uprzednim zaznajomieniu się z głównymi nurtami myślowymi Zachodu. Od 1920 roku poniechał niemal całkowicie dalszych badań nad scholastyką polską, przeszedł do poszukiwania jej źródeł i podjął studia nad głównymi prądami filozofii zachodnioeuropejskiej xIV stulecia. W swych badaniach interesował się nie szkołami, nie systemami filozoficznymi, ale przede wszystkim zagadnieniami podejmowanymi w XIV stuleciu, ich sformułowaniami oraz proponowanymi dla nich rozwiązaniami.

Michalski był pierwszym w Polsce uczonym, który badania w zakresie historii filozofii postawił na europejskim poziomie, sięgając wprost do źródeł i prowadząc studia samodzielnie na odcinkach przed nim mało zbadanych lub prawie nieznanych. Był zarazem pierwszym uczonym polskim, który pracując nad wyjaśnieniem głównych prądów w filozofii późniejszego średniowiecza na terenie Francji i Anglii w wieku XIV, wniósł w tej dziedzinie trwały i istotny dorobek w naukę europejską. W bibliotekach polskich, angielskich, francuskich, niemieckich i włoskich przebadał pod względem historyczno-krytycznym ponad 360 rękopisów filozoficznych. Wykazał wiele zbieżności problemowo-doktrynalnych, analogii i pokrewieństw występujących pomiędzy filozofią średniowieczną a nowożytną i współczesną. Na trwałe wszedł do fundamentalnych podręczników filozofii średniowiecznej.

\section{Słowa kluczowe}

Michalski Konstanty, historia filozofii, scholastyka, średniowieczna filozofia polska, Corpus Philosophorum Medii Aevi, Dante Alighieri, Uniwersytet Jagielloński

\section{Summary}

\section{Konstanty Michalski, CM, a Historian of Medieval Philosophy}

Rev. Konstanty Michalski, CM, (1879-1947), a philosopher, historian of philosophy, professor and rector of the Jagiellonian University as well as an active member of the Historical-Philosophical Department of the Polish Academy of Learning; he was chairman of the Commission of the History of Philosophy in Poland and Vice-Director of the Department. He experienced the horrors of the concentration camp in Sachsenhausen near Berlin. Michalski's academic achievements in the field of the history of medieval thought include three thematic groups: Polish philosophy, Western philosophy and philosophical-theological thought of Dante Alighieri. 
While investigating the $14^{\text {th }}$ century philosophical trends and problems of Scholasticism, Michalski concluded that the dynamics of mediaeval thought was strictly related to the reception of Aristotle's works and their Arabic and Greek commentators. Together with Aleksander Birkenmajer he put forward a project of a critical edition of the Latin translations of Aristotle's works, Latin translations of the Arabic and Jewish thinkers as well as the best medieval commentaries on the works of the Stagirite and independent philosophical treatises. On behalf of the Polish Academy of Learning Michalski presented a project of the editorial series Corpus Philosophorum Medii Aevii to the Union Académique Internationale (International Union of Academies) in Brussels in 1928. The Union accepted the proposal of the two medievalists from Kraków in 1930. Michalski gave great impetus to Aristotelian studies, which made medievalists continue their work until today. Corpus Philosophorum Medii Aevii is the most significant and greatest contribution to research on mediaeval thought, continued by scientific centres in Poland and abroad. Michalski reached the conclusion that only getting familiar with the main Western trends would allow him to fathom the doctrinal currents of Polish medieval philosophy. From 1920, he stopped investigating Polish Scholasticism and began seeking its sources in the main trends of Western philosophy of the 14 century. He was not so much interested in schools and systems as in the issues discussed in the $14^{\text {th }}$ century, their formulations and proposed solutions.

Michalski was the first Polish scholar who raised research on the history of philosophy to a European level by investigating the sources and carrying out independent studies on fields that had been little known or examined. At the same time, he was the first Polish scholar who explored the main trends in the $14^{\text {th }}$ century philosophy in France and England, contributing to European science to a considerable extent. His achievements are permanent and notable. He studied from the historical-critical perspective over 360 philosophical texts in Polish, English, French, German and Italian libraries. He showed numerous parallels, analogies and similarities in problem-doctrinal areas between medieval philosophy on the one hand and modern and contemporary philosophy on the other. The outcome of his research activities has been included permanently in fundamental textbooks for medieval philosophy.

\section{Keywords}

Michalski Konstanty, history of philosophy, scholastics, medieval Polish philosophy, Corpus Philosophorum Medii Aevi, Dante Alighieri, Jagiellonian University 